\title{
Bilateral Investment Treaties dan Penyelesaian Arbritase Internasional (Studi Kasus Pencabutan Izin Kuasa Pertambangan Churchill Mining)
}

\author{
Yacob Rihwanto \\ Pascasarjana Fakultas Hukum Universitas Islam Indonesia \\ Jln. Cik Ditiro No. 1 Yogyakarta \\ yacobrihwanto@yahoo.com
}

\begin{abstract}
The aim of BITs is to protect the investment in foreign countries, enhance the market-oriented policy and create the practice of transparent and non-discriminant between state and investors. This research studied about some issues: first, how is the impact of Bilateral Investment Treaties (BITs) on the investment climate in the developing countries particularly in Indonesia? Second, how is the process of conflict solution if there is a conflict in Bilateral Investment Treaties? This is a normative research using the regulation approach. The research concluded that first; the implementation of the agreement of BITs conducted by Indonesia at the moment has led Indonesia as the host country to the loss and the contract is no longer relevant and needs to be revised. Second if there is a conflict, it can be solved through ICSID as an arbitrary institution towards the lawsuit of investment between states signing the contract of BITS.
\end{abstract}

Keywords: Lawsuit, investment, international arbitration

\begin{abstract}
Abstrak
Tujuan BITs melindungi investasi di luar negeri, meningkatkan kebijakan yang berorientasi pasar dan menciptakan praktek investasi yang transparan dan non diskriminasi antara Negara dan investor. Penelitian ini mengkaji permasalahan: pertama, bagaimanakah dampak Bilateral Investment Treaties (BITs) terhadap iklim investasi di negara berkembang, terutama Indonesia? Kedua, bagaimanakah proses penyelesaian sengketa apabila terjadi perselisihan dalam Bilateral Investment Treaties? Penelitian ini merupakan penelitian normatif dengan pendekatan perundang undangan. Hasil penelitian menunjukkan bahwa: pertama, pelaksaan perjanjian BIT yang dilaksanakan oleh Indonesia pada saat ini dirasa telah banyak merugikan Indonesia sebagai host country dan menganggap perjanjian tersebut sudah tidak relevan lagi dan perlu untuk diadakannya pembaharuan perjanjian BIT. Kedua, jika terjadi sengketa dapat diselesaikan melalui ICSID sebagai lembaga arbitrase sengketa investasi antara negara yang menandatangi perjanjian BITs.
\end{abstract}

Kata kunci : Bilateral investment treaties (BITs), sengketa, arbitrase internasional 


\section{Pendahuluan}

Pengaturan mengenai penanaman modal asing ini dahulu diatur dalam UU No. 1 Tahun 1967 tentang Penanaman Modal Asing sebagaimana telah diubah dengan UU No. 11 Tahun 1970 tentang Perubahan dan Tambahan UU No. 1 Tahun 1967 tentang Penanaman Modal Asing dan UU No. 6 Tahun 1968 tentang Penanaman Modal Dalam Negeri sebagaimana telah diubah dengan UU No. 12 Tahun 1970 tentang Perubahan dan Tambahan UU No. 6 Tahun 1968 tentang Penanaman Modal Dalam Negeri karena semakin berkembangnya zaman dan undang-undang tersebut dirasa sudah tidak sesuai lagi dengan kebutuhan percepatan pembangunan dan perkembangan hukum nasional, maka kedua undang-undang tersebut diubah menjadi UU No. 25 Tahun 2007 tentang Penanaman Modal. Undang-undang tersebut menyatukan pengaturan mengenai penanam modal asing dan penanam modal dalam negeri. Dengan kata lain tidak ada lagi perbedaan ketentuan antara penanaman modal asing dengan penanaman modal dalam negeri. Undang-Undang Penanaman Modal ini dimaksud untuk memberikan kepastian hukum. ${ }^{1}$

Menurut UNCTAD (1995), ada delapan perjanjian bilateral dan multilateral yang biasanya berlaku untuk investasi, yaitu Provisions on Capital Movement (PCM), Provisions on Foreign Borrowing (PFB), Double Taxation treaties (DTT), Insurances Guarantees dalam MIGA, Washington Convention on the Settlement of Investment Disputes (WCSID), Preferential Trade Agreement (PTA), dan Bilateral Investment Treaties (BIT). ${ }^{2}$

Dalam kerjasama bilateral, negara-negara menjalin hubungan yang bersifat resiprokal. Perlakuan suatu negara terhadap tiap-tiap investor harus sama agar ada jaminan masuknya investor. Dalam hal investasi, lembaga perjanjian bilateral telah dikenal sejak decade 1970-an dalam kerangka International Guarantee Agreement (IGA). Dua negara yang membangun kerjasama bilateral dalam investasi menandatangani Bilateral Investment Treaty (BIT). ${ }^{3}$ Dalam BIT telah diatur bagaimana jaminan dan perlindungan investasi di kedua negara, terutama dalam hal kepastian usaha, jaminan keamanan, dan penyelesaian perselisihan investasi asing di masing-masing negara.

BIT sebagai perjanjian bilateral (bilateral treaty) biasanya menjadi fondasi yang membangun perjanjian multilateral (multilateral treaty) di kemudian hari, jika Negaranegara dalam satu rumpun dan memiliki kepentingan yang sama membentuk suatu bilateral

\footnotetext{
${ }^{1}$ Sentosa Sembiring, Hukum Investasi, Nuansa Aulia, Bandung, 2010, hlm. 21.

2 Johnny W. Situmorang, Menguak Iklim Indonesia Pascakrisis, ESENSI, Jakarta, 2011, hlm. 142

${ }^{3}$ Dalam terminologi Indonesia diartikan sebagai Persetujuan Peningkatan dan Perlindungan Penanaman Modal (P4M)
} 
treaty, maka bukan tidak mungkin di kemudian hari tercipta multilateral treaty. Pada umunya, perjanjian yang melibatkan negara ini lebih disukai daripada perjanjian antar dua negara, karena perjanjian tersebut menyederhanakan sistem ekonomi internasional dan memiliki norma lebih mengikat. Di sisi lain, perjanjian bilateral juga banyak dipilih sebagai langkah pertama untuk menyelesaian permasalahan yang sangat rumit (highly contentious issue) misalnya yang berhubungan dengan foreign direct investment (FDI) karena perjanjian bilateral hanya melibakan dua piak dengan kepentingan berbeda.

Di Indonesia sampai saat ini terdapat sekitar 66 perjanjian bilateral yang sudah ditandatangani, akan tetapi di dalam pelakasanaannya, tentu saja terdapat kendala-kendala yang mengakibatkan terjadinya konflik antara Indonesia dengan negara penanam modal. Terdapat beberapa kasus yang pada kenyataannya pemerintah Indonesia digugat oleh penanam modal asing dikarenakan menurut pihak penanam modal asing tersebut kebijakan yang dibuat oleh pemerintah Indonesia merugikan mereka. ${ }^{4}$

Alasan yang mendasari proyek perombakan BIT besar-besaran ini ialah karena kasus Indonesia dengan perusahaan besar asal United Kingdom yaitu Churchill Mining ply. Churchill membawa kasus dengan pemerintah Indonesia ke hadapan Arbitrase ICSID atas tuntutan bahwa aset batubara yang dimilikinya di Kalimantan Timur telah dirampas oleh Pemerinta Daerah Kutai Timur tanpa ganti rugi yang pantas dengan mencabut izin kuasa pertambangannya. Kasus ini menunutut Indonesia untuk mengganti USD \$ 2.000.000.000,00 kepada Churchill atas pelanggaran yan dilakukan Indonesia berdasarkan kesepakatan BIT antara Indonesia dan UK. ${ }^{5}$

Persoalan yang menimpa Churchill juga dialami oleh beberapa perusahaan PMA di bidang pertambangan lainnya. Beberapa perusahaan pertambangan memperoleh konsesi tambang di beberapa daerah berdasarkan kebijakan pemerintah sebelumnya, namun pada periode selanjutnya Menteri Kehutanan menyatakan larangan eksploitasi pertambangan oleh 14 perusahaan karena konsesi tambanganya masuk ke dalam area hutan taman nasional. Karena kebijakan itu, lima perusahaan merasakan kerugian dan melaporkan ke Badan Pelaksana, yaitu Wirabuana Petrolindo, Conoco Philips, Coparex, Jambi Merang dan Caltex. Manajemen perusahaan-perusahaan yang sudah terkena larangan itu mengajukan keberatan dengan alasan sudah mengeluarkan biaya yang tinggi untuk eksplorasi dan penyiapan eksploitasinya. ${ }^{6}$

\footnotetext{
${ }^{4}$ Citra Mutiara Virjinia, "Pelaksanaan Bilateral Investment Treaties (BIT) Dalam Penanaman Modal Asing d iIndonesia Berdasarkan Undang-Undang No. 25 Tahun 2007 tentang Penanaman Modal”, Jurnal Universitas Padjajaran.

5 Fitri Novia Heriani dan Robert Sidauruk, Govt Requests ICSID to Discontinue Churchill Mining, Case, http://en.hukumonline.com/pages/lt53c3903dc8295/govt-requests-icsid-to discontinue-churchill-mining-case, diakses pada 24 Juni 2015.

6 Johnny W. Situmorang, Op. Cit., hlm. 250-251
} 
Pernyataan The Financial Times pada 26 Maret 2014 bahwa "Indonesia to terminate more than 60 bilateral investment treaties" bukanlah berarti niat Indonesia untuk membatalkan semua BIT, melainkan Indonesia ingin mengehentikan BITs yang sedang berjalan sesuai dengan jangka waktu yang diberikan dalam perjanjian. Beradasarkan hukum, hak ini tidak illegal atau nasionalistik. Padahal akibat dari pernyataan tersebut, Indonesia menerima banyak reaksi keras dari akademisi maupun pebisnis di seluruh dunia karena ditakutkan tanpa adanya BIT para investor tidak mendapat perlindungan dan jaminan kepastian hukum ketika melakukan usaha di Indoensia. ${ }^{7}$

Fakta bahwa Indonesia memiliki 67 BIT dari beberapa negara dengan berbagai bentuk dan isi mengakibatkan Indonesia perlu mengadakan sebuah standarisisasi BIT atau Indonesia membiarkan setiap BIT yang dinegosiasi dan ditandatangani secara sendirisendiri tanpa memperhatikan konsistensi dan perubahan dunia. Sebenarnya tidak masalah bagi Indonesia untuk meng-update dan memperbarui dan menyeimbangkan peraturannya dengan BIT. Hanya saja para protestan yang terkejut atas kepuusan bangsa Indonesia tersebut. $^{8}$

\section{Rumusan Masalah}

Adapun permasalahan dalam penelitian ini, pertama, bagaimanakah dampak Bilateral Investment Treaties (BITs) terhadap iklim investasi di negara berkembang, terutama Indonesia? Kedua, bagaimanakah proses penyelesaian sengketa apabila terjadi perselisihan dalam Bilateral Investment Treaties?

\section{Tujuan Penelitian}

Adapun tujuan dalam penelitian ini adalah, pertama, untuk mengatahui dampak Bilateral Investment Treaties (BITs) terhadap iklim investasi di negara berkembang, terutama Indonesia. Kedua, proses penyelesaian sengketa apabila terjadi perselisihan dalam Bilateral Investment Treaties.

\footnotetext{
7 Michael Ewing-Chow and Junianto James Losari, Indonesia should not withdraw from the ICSID, http://www.thejakartapost.com/news/2014/04/24/indonesia-should-not-withdrawicsid.html\#sthash.J2yLFQro.dpuf, edisi April 242014.

8http:/ / www.thejakartapost.com/news/2014/07/07/revamping.bilateraltreaties.html\#sthash.CINhOB8 d.dpuf edisi 7 Juli 2014
} 


\section{Metode Penelitian}

Metodologi (Methodology) dalam arti umum adalah studi yang logis dan sistematis tentang prinsip-prinsip yang mengarahkan penelitian ilmiah, dengan demikian metodologi dimaksudkan sebagai prinsip-prinsip dasar dan bukan sebagai cara-cara untuk melakukan penelitian. ${ }^{9}$ Sementara itu, metode dapat dipahami sebagai cara-cara untuk melakukan penelitian. Selanjutnya penelitian merupakan terjemahan dari Bahasa Inggris, yaitu research. Kata research berasal dari re (kembali) dan to search (mencari). Research berarti mencari kembali. Oleh karena itu, penelitian pada dasarnya merupakan "suatu upaya pencarian" dengan usaha pencarian pengetahuan yang benar. ${ }^{10}$

Penelitian secara umum diartikan sebagai sarana pokok dalam pengembangan ilmu pengetahuan dan teknologi. Keterkaitannya dengan penelitian hukum adalah suatu proses untuk menemukan aturan hukum, prinsip-prinsip hukum, maupun doktrin-doktrin hukum, guna menjawab isu hukum yang dihadapi. ${ }^{11}$

Terkait dengan penulisan ini, tipe penelitian yang digunakan adalah yuridis normatif (legal research), yaitu penelitian yang difokuskan untuk mengkaji penerapan kaidah-kaidah atau norma-norma dalam hukum positif. Tipe penelitian yuridis normatif dilakukan dengan mengkaji berbagai macam aturan hukum yang bersifat formal seperti undang-undang, literatur-literatur yang bersifat konsep teoritis yang kemudian dihubungkan dengan permasalahan yang menjadi pokok pembahasan. ${ }^{12}$

\section{Hasil Penelitian dan Pembahasan}

\section{BITs sebagai Proteksi Investasi bagi Investor Asing terhadap Kebijakan Pemerintah Host Country}

Sebelum berkembangnya Perjanjian Investasi Antar dua negara (Bilateral Investment Treaties/BITs), hukum kebiasaan internasional yang mengatur investasi asing memberikan perlindungan yang sangat lemah terhadap investasi asing. Dulunya, hukum internasional yang melindungi investor asing merupakan bagian dari hukum umum yang mengatur tanggungjawab negara terhadap pihak asing (the general law on state responsibility for injuries to aliens).

${ }^{9}$ Sumardjono, Maria S.W. Pedoman Pembuatan Usulan Penelitian Sebuah Panduan Dasar, PT. Gramedia Pustaka Utama, Jakarta, 1997, hlm. 8.

${ }_{10}$ Zainuddin Ali, Metode Penelitian Hukum, Sinar Grafika Ofsset, Jakarta, 2009, hlm. 1.

11 Peter Mahmud Marzuki, Penelitian Hukum, Kencana Persada Group, Jakarta, 2010, hlm. 35.

12 Johny Ibrahim, Teori Metodolgi Penelitian Hukum Normatif, Banyu Media, Malang, 2008, hlm. 295. 


\section{LEx Renaissance No. 1 VOL. 1 JANUARI 2016: 107 - 125}

Hanya negara asal dari investor asing yang mengalami ekspropriasi yang dapat meminta ganti rugi, bukan investor itu sendiri dalam mengajukan tuntutan. Terlebih lagi, suatu pelanggaran kontrak sederhana antara host state dan investor asing tidak menimbulkan unutan apapun atas dasar state responsibility, melainkan host state bertanggung jawabhanya kepada home state atas prinsip breach of the "minimum standard" for the treatment of the foreigner. ${ }^{13}$

BITs saat ini menjadi sumber hukum internasional yang paling dominan dianggap untuk melindungi investasi asing di negara berkembang. Sebaliknya, sangat jarang sekali BIT yang ditandatangani antar sesama negara maju, dimungkinkan karena para investor tersebut yakin bahwa negara tuan rumah dari negara maju telah memiliki domestic law yang memadai dan tidak akan melakukan diskriminasi. ${ }^{14}$

Azas yang terkandung dalam BIT adalah most favored nations (MFN), yakni untuk menjamin kesamaan pemeberian perlakuan kepada negara yang bekerjasama dengan suatu negara, larangan pengambilalihan, nasionalisasi, pencabutan hukum, jaminan transfer mata uang dan jaminan subrogasi untuk mengatasi resiko nonkomersial.

Meskipun terdapat lebih dari 2,600 BIT berbeda yang berlaku di dunia, kebanyak di antara mereka memiliki keseragaman peraturan dan perlindungan. ${ }^{15}$ Hal ini dapat dilihat dari kesamaan struktur dan isi BIT masing-masing negara yang secara umum mengatur empat buah substansi yakni: "(1) conditions for the admission of foreign investors to the host State; (2) standards of treatment of foreign investors; (3) protections against expropriation; and (4) methods for resolving investment disputes. "16

Tujuan utama BIT seharusnya dapat menugrangi resiko non-ekonomi dan dengannya membuka kesempatan investasi. BITs dapat mengurangi resiko non-ekonomi dengan membentuk standar perlakuan investasi asing yang secara hukum dapat diberlakukan. BITs seharusnya mengutamakan dan melindungi investasi dengan diiringi mekanisme lainnya. Apakah BIT sendiri benar-benar dapat meningkatkan FDI masih dipertanyakan, sebab keberadaan perjanjian bilateral hanyalah merupakan satu di antara banyak factor yang dapat mempengaruhi keputusan investor potensial dalam menginvestasikan modalnya di suatu negara berkembang. Faktor lain yang patut dipertimbangkan ialah stabilitas politik host country; kerangka kebijakan ekonomi, industri, dan administratif; keuntungan ekonomi dari investasi

13 Ryan J. Bubb dan Susan Rose-Ackerman, BITs and Bargains: Strategic Aspects of Bilateral and Multilateral Regulation Of Foreign Investment, 27 Int'l Rev. L. \& Econ. 291 (2007), hlm. 3

14 Ibid hlm. 469

${ }^{15}$ Kenneth J. Vandevelde, The Economics of Bilateral Investment Treaties, 41 HARV. INT'L L.J. 469, 471 (2000),

16 Jarrod Wong, Umbrella Clauses in Bilateral Investment Treaties: Of Breaches of Contract, Treaty Violations, and the Divide Between Developing and Developed Countries in Foreign Investment Disputes, 14 Geo. Mason L. Rev. 135, 141 (2006), hlm. 141 
awal atau peningkatan dalam investasi yang sedang berlangsung; dan paket insentif atau pilihan pengaturan investasi yang baru. Praktiknya, kecuali host country dapat memberikan modal profit-making yang aman kepada investor asing, maka bilateral treaty saja tidak akan menarik investor. ${ }^{17}$

Tujuan utama suatu BITs adalah untuk meningkatkan promosi dan proteksi "reciprocal encouragement" investasi di wilayah asal masing-masing perusahaan. Tujuan utama BITs adalah untuk melindungi investasi di luar negeri, meningkatkan kebijakan yang berorientas pasar dan menciptakan praktek investasi yang transparan dan non diskriminasi antara negara dan investor, dan untuk mendukung perkembangan standar hukum internasional yang sejalan dengan tujuan-tujuan tersebut. ${ }^{18}$

Penyelesaian perselisihan lebih diutamakan melalui perundingan, bila tidak tercapai diajukan ke arbitrase internasional, baik melalui International Center for Settlement Disoute (ICSID) maupun United Nations Commission on International Trade (UNCITRAL). Dengan demikian, secara prinsip Msalah iklim investasi yang tidak kondusif dapat diatasi dengan BIT. Namun, walaupun instrument BIT sangat strategis untuk membangun hubungan internasional, faktanya Indonesia belum bias secara total memanfaatkan BIT untuk memperbesar kapasitasnya di kancah perekonomian internasional. ${ }^{19}$

BITs menyediakan sistem penyelesaian sengketa yang memberikan kewenangan bagi investor untuk secara langsung menggunakan hak-haknya yang diatur dalam BIT. ${ }^{20}$ Peraturan tentang penyelesaian sengketa biasanya mengizinkan investor secara pribadi untuk "submit an investment dispute between it [self] and a Contracting State to the investor's choice of forum...". 21

Motivasi untuk memasukkan perlindungan dengan memberikan hak bagi investor mengajukan klaim penyelesaian sengketa secara pribadi didasarkan pada kenyataan bahwa "[h]ost governments can easily change their own domestic law after a foreign investment is made, and host country officials may not always act fairly or impartially toward foreign

${ }^{17}$ Michael R. Reading, The Bilateral Investment Treaty in Asean: A Comparative Analysis, 42 Duke L.J. 679 (1992), hlm. 2-3

18 Sara Jamieson, A Model Future: The Future of Foreign Direct Investment and Bilateral Investment Treaties, 53 S. Tex. L. Rev. 605 (2012), hlm. 3

19 Johnny W. Situmorang, Op. Cit., hlm. 143-145

20 Jarrod Wong, Op. Cit., hlm. 142

21 Jarrod Wong, Ibid. 


\section{Ifx Renaissance No. 1 VOL. 1 JANUARI 2016: 107 - 125}

investors and their enterprises. "22 Dengan demikian, keberatan investor terhadap sistem hukum dalam negeri host country dapat dijembatani. ${ }^{23}$

Dengan demikian, perlindungan langsung dari resiko non-ekonomi (risk reduction) dan kerjasama dengan perangkat aturan lainnya yang bertujuan untuk mengurangi resiko harus dipertimbangkan sebagai tujuan utama BIT. Meningkatnya investasi pada akhirnya hanyalah produk dari tujuan-tujuan ini dan BIT akan lebih efektif ketika dimanfaatkan bersaman dengan mekanisme lainnya. BITs dapat menjadi arah bagi lembaga hukum dan perjanjian lainnya, misalnya perjanjian perpajakan, jaminan resiko politik, Investment Guarantee Agreements (IGAs), hukum lokal dari host country dan home country, kontrak investasi antara investor asing dan host country, dan perjanjian perlindungan Hak Kekayaan Intelektual.

\section{Permasalahan dalam BIT, Tarik Menarik Kepentingan antara Investor Asing dan Pemerintah Lokal Host Country}

Ekonom beraliran Marxis telah mengakarakteristikkan investasi asing sebagai rekolonialisasi terhadap host country. Alas an atas karakterisasi ini adalah disebabkan BITs memberikan control kepada asing untuk mendominasi ekonomi dalam negeri dengan mendistribusi domestic wealth dan kekuasaan melalui peralihan control asset local kepada perusahaan asing. ${ }^{24}$

Secara umum, control didapatkan dari adanya perjanjian BITs yang memperblehkan investor asing masuk ke dalam negara berkembang dan membeli beragam aset dalam negeri yang pada dasarnya memberkan kuasa asing atas sumber daya dalam negeri. Namun, FDI tidak selamanya buruk sebab secara teoritis, investasi dapat memberikan modal asing, lapangan pekerjaan, teknologi, peningkatan produksi dalam negeri, dan pasar atau pelaku pasar dalam negeri lebih berkembang. Ditambah lagi, peraturan yang mewajibkan ADR memberikan kuasa bagi insitusi neral unuk menyelesaikan sengkera yang secara ideal dapat menghasilkan keputusan yang cepat dan akurat terkait BITs dan kewajiban Negara yang menandatanganinya. ${ }^{25}$

22 Jeswald W. Salacuse \& Nicholas P. Sullivan, Do BITs Really Work?: An Evaluation of Bilateral Investment Treaties and Their Grand Bargain, 46 Harv. Int'l L.J. 67, 67 (2005), hlm. 75

${ }^{23}$ Dr. Efraim Chalamish, The Future of Bilateral Investment Treaties: A De Facto Multilateral Agreement?, 34 Brook. J. Int'l L. 303, 307-08 (2009), hlm. 316

${ }^{24}$ Joshua Boone, How Developing Countries Can Adapt Current Bilateral Investment Treaties To Provide Benefits To Their Domestic Economies, GLOBAL BUSINESS LAW REVIEW, Vol. 1:187 (2011), hlm. 190.

25 Ibid 
BITs, di sisi lain, dapat berperan sebagai katalis untuk pergerakan "hot money" dari Negara berkembang ke Negara asal investor (yang umumnya Negara maju). Ini sangat mungkin terjadi karena peraturan BITs yang mengizinkan repatriasi bebas atas investasi asing. Repatriasi bebas memungkinkan investor untuk dengan cepat "take their money and run" dalam kondisi tertentu, terutama ketika adanya tanda-tanda kekacauan politik, social, atau ekonomi di host country tanpa adanya hukuman atau konsekuensi moneter. ${ }^{26}$

BITs, khususnya perjanjian generasi awal, berisi peraturan yang kurang teliti (imprecise) dan ketika mengarah pada pengaturan penyelesaian sengketa di hadapan arbitrase internasional, memberikan lingkup sangat luas berdasarkan putusan yang tidak konsisten dan tidak dapat diprediksi. Kesadaran defisiensi penyelesaiana sengketa antara investor dengan host country juga terjadi karena sifat pengadilan arbitrase yang sementara (ad hoc), kurangnya transaparansi dan legitimasi. Permasalahan muncul karena yurisprudensi pada pengadilan ini sangat beragam dan tidak adanya proses banding sehingga mengurangi standar kebenaran dan konsistensi hukum. Peraturan perjanjian yang tidak teliti, putusan arbitrase yang tidak konsisten, dikombinasikan dengan meningkatnya jumlah tuntutan investor yang menantang kebijakan poliik pemerintah host country, menjadi perhatian bagi banyak kalangan terhadap keberadaan BITs bagi negara berkembang. ${ }^{27}$

Meskipun BITs diklaim sebagai perjanjian timbal balik (reciprocal) antara pihak yang terikat di dalamnya, pada faktanya perjanjian BITs tidak simetris. BITs terlihat setara karena mengatur bahwa warga negara maupun perusahaan dari masing-masing negara dapat berinvestasi di wilayah satu sama lain dengan perlindungan yang setara. Mesipun demikian, kebanyakan BITs yang ditandatangani adalah antara negara maju dengan negara berkembang. Ketidakseimbangan tercipta di antara keduanya dengan posisi tawar relatif yang dimiliki masing-masing negara tersebut dan arah dari perpindahan modal. Biasanya, negara industri menjadi sumber investasi sedangkan negara berkembang menjadi penerima. ${ }^{28}$

Selanjutnya, BITs yang mewujudkan tujuan peningkatan investasi akan terwujud oleh kemampuan host country menciptakan lingkungan investasi yang ramah dan stabil. Sehingga, keberhasilan peningkatan FDI pada suatu negara sebenarnya bukan karena peraturan yang

26 Tom Ginsburg, International Substitutes for Domestic Institutions: Bilateral Investment Treaties and Governance, 25 INT'L REV. L. \& ECON. 107, 108 (2005), hlm. 111-112

${ }_{27}$ Xavier Carim, Lessons from South Africa's BITs Review, Columbia FDI Perspectives, Perspectives on topical foreign direct investment issues by the Vale Columbia Center on Sustainable International Investment No. 109, November 25, 2013, hlm.

${ }^{28}$ Jeswald W. Salacuse \& Nicholas P. Sullivan, Op. Cit., hlm. 95 


\section{IEx Renaissance No. 1 VOL. 1 JANUARI 2016: 107 - 125}

ditentukan dalam BIT, melainkan keputusan investor itu senditi untuk berinvestasi di suatu wilayah negara. ${ }^{29}$

Membuat dan menjalankan sebuah perjanjian membutukan tawar menawar dimana kedua belah pihak yakin mereka akan mendapatkan keuntungan. Suatu perjanjian investasi si antara dua negara maju, keduanya sama-sama berharap dapat berinvestasi di wilayah satu sama lain, memang dapat mewujudkan prinsip resiprositas dan perlindungan bersama. Namun, tawar menawar ini biasanya tidak berlaku untuk perjanjian antara negara maju yang berbasis eskpor modal dan negara miskin yaitu negara berkembang yang warga negaranya jarang berinvestasi keluar negeri. Jawaban dari pertanyaan ini adalah negara berkembang menandatangani BITs untuk mempromosikan investasi asing, dengannya akan terjadi peningkatan jumlah modal dan teknologi terapan yang beralih ke wilayah mereka. Asumsi dasar dibalik BIT yakni bahwa suatu perjanjian bilateral denan peraturan yang jelas dan dapat dilaksanakan untuk melindungi dan memfasilitasi invesasi asing menurangi resiko yang bias saja dapat dihadapi investor dan pengurangan resiko tersebut meningkatkan investasi. ${ }^{30}$

Pada 1980an dan 1990an, karena bantuan keuangan dari bank-bank komersiap dan lembaga bantuan resmi menipis, negara-negara berkembang mulai meningktakan investasi asing untuk meningjatkan pembangunan ekonomi. Negara-negara berkembang tersebut melihat BITs sebagai satu cara untuk mengkampanyekan promosi investasi dan untuk itu berbondong-bondong menandatanganinya. Jadi, BIT antara negara maju dan negara berkembang didasarkan pada tawar menawar, yaitu janji atas perlindungan modal sebagai ganti untuk prospek modal yang lebih besar di masa depan. ${ }^{31}$

Dalam konteks BITs, promosi investasi bagi host country berarti penarikan proyek investasi yang ditentukan oleh host country berdasarkan best interest-nya. Liberalisasi investasi merupakan istilah favorit dari negara-negara pemilik modal dan pada umumnya berarti membuat iklim investasi yang dapat dianggap investor memenuhi best interest mereka. Misalnya, suatu pemerintah host country secara aktif berusaha menarik investasi di bidang industri elektronik, yang dikiranya dapat mempercepat pembangunan ekonominya di masa depan tetapi belum terwujud di negerinya. Pada waktu yang bersamaan, pemerintah tersebut juga ingin menghambat investasi di bidang retail yang telah disediakan oleh pengusaha lokal yang secara politik kuat namun takut dengan persaingan dengan pihak asing. Pada situasi tersebut, melalui hubungan perjanjian dan peraturan perundang-undangannya, negara 
berkembang akan mengikuti kebijakan prningkatan investasi tetapi bukan liberalisasi investasi. $^{32}$

Sistem penyelesaian sengketa yang diatur dalam BITs, berdasarkan pandangan investor swasta, sistem hukum host country terbukti tidak cukup untuk menyelsaikan sengketa dari investasi langsung di negara tersebut. Meskipun demikian, pandangan ini arus diimbangi dengan state sovereign right untuk mengatur dan mengontrol hukum nasionalnya. ${ }^{33}$ Negara juga memiliki kepentingan besar untuk menarik investasi asing dan menghilangkan kekhawatiran investor, untuk keadaan tersebut, negara telah merubah prioritas mereka terhadap aspek kedaulatan (sovereign aspects) dan sustem penyelesaian sengketa saat ini "normally perceived as a necessary consequence of an investment-friendly climate rather than a negative aspect... ."34

Selain itu, beberapa substantive rules yang terkandung dalam BIT dapat berakibat pada hukum dalam negeri suatu negara. Model klausul yang diaur dalam perjanjuan dengan dampak tersebut biasanya berhubungan dengan indirect expropriation, perlakuan fair dan equitable untuk investor asing, dan kalusul yang berhubungan dengan perjanjian perlindungan investasi yang dibuar antara investor dengan host country (klausul paying, disebut umberellah clause). ${ }^{35}$ Berdasarkan eskpropriasi, hamper semya BITs (terutama antara negara maju dengan negara berkembang) mengadopsi pandangan tradisional barat bahwa negara tidak boleh mengekspropriasi asset investor asing dengan satu pengecualian. ${ }^{36}$

Meskipun demikian, perbedaan kunci peraturan ini berisi standar kompensasi, meskipun mencantumkan kalimat "prompt, adequate, and effective."37 Persyaratan perlakuan yang adil dan merata merupakan standar perlakuan di dalam BITs dan hukum kebiasaan internasional. Perdebatan atas isi dari persyaratam ini semakin banyak dan pengadilan mulai menekankan pada stability, consistency, dan transparency dari perilaku administrative dalam negeri untuk menghindari masalah dalam bidang ini. ${ }^{38}$ Pada prakteknya, prinsip ini memberikan efek yang sangat luas terhadap kedaulatan suatu bangsa dan bagaimana suau negara menentukan dan memberlakukannya itu dalam hukum tata usahanya. $^{39}$

${ }^{32}$ Ibid., hlm. 6.

${ }^{33}$ Rudolf Dolzer, The Impact of International Investment Treaties on Domestic Administrative Law, 37 N.Y.U. J. Int'l L. \& Pol. 953, passim (2005), hlm. 964

${ }^{34}$ Ibid., hlm. 955

${ }^{35}$ Ibid., hlm. 957-958

36 Salacause, Op. Cit., hlm. 87

37 Ibid

38 Dolzer, Op. Cit., hlm. 961-964.

39 Ibid., hlm. 964 
BITs sesungguhnya memberikan peran dobel kepada negara yaitu sebagai Anggota Kontrak, mereka menginterpreasikan kepentingan langsungnya ke dalam perjanjian dan pada saat yang bersamaan mereka membuka kesempatan bagi dirinya sendiri untuk menjadi tergugat dalam suatu perselisihan dimana mereka memiliki kepentingan lasung untuk menghindari tanggungjawab ${ }^{40}$. Ketika para pihak memberikan hak-hak tertentu kepada pengadilan investasi, termasuk kuasa untuk menyelsaikan sengketa, pendelegasian kekuasaan untuk menginterpretasikan bersifat "implied and partial, rather than express and exclusive." ${ }^{41}$ Kekurangan utama di dalam interpretative power berasal dari kesalahan para pihak untuk bekerjasama dan meyakinkan bawa suatu hak interpretasi tertentu diberikan kepada dewan arbitrase. ${ }^{42}$ Dengannya, pengadilan arbitrase seringkali gagal untuk menghargai peran dobel suatu negara sebagai pihak dalam perjanjian dan juga tergugat dalam kewenangan interpretasinya sendiri sebagai berbagai daripada ekslusif. ${ }^{43}$

\section{Yurisdiksi ICSID sebagai Forum Penyelesaian Sengketa antara Churchill Mining plc. vs Pemerintah Indonesia}

Tujuan dibentuknya ICSID adalah untuk menyediakan fasilitas bagi konsiliasi dan arbitrase sengketa investasi antara negara peserta konvensi dengan warga negara dari negara peserta konvensi lainnya berdasarkan ketentuan konvensi. Agar ICSID dapat berlaku, para pihak harus sepakat mengajukan sengketa ke dewan Arbitrase ICSID dan sengketa haruslah berkaitan dengan masalah investasi. ${ }^{44}$

Dalam Undang-Undang Minerba telah diatur bahwa setiap sengketa yang muncul dalam pelaksanaan IUP, IPR atau IUPK diselesaikan melalui pengadilan dan arbitrase dalam negeri sesuai dengan ketentuan peraturan perundang-undangan, ${ }^{45}$ sedangkan segala akibat hukum yang timbul karena penghentian sementara dan/atau pencabutan IUP, IPR atau IUPK diselesaikan dengan ketentuan peraturan perundang-undangan. ${ }^{46}$

Berdasarkan UU Minerba dan penjelasannya, tidak disebutkan mekanisme alternative penyelesaian sengketa tertentu untuk menyelesaikan pencabutan IUP, IPR atau IUPK tersebut. Adapun Churchill Mining plc mendasarkan tuntutan terhadap Pemerintah

40 Anthea Roberts, Power and Persuasion in Investment Treaty Interpretation: The Dual Role of tates, 104

Am. J. Int'l L. 179, 179 (2010), hlm. 182

${ }^{41}$ Ibid., hlm. 188

${ }^{42}$ Andrew Newcombe \& Lluis Paradell, Law and Practice of Investment Treaties: Standards of Treatment \$2.30 (Kluwer Law International 2009) dalam Sara Jamieson, Op. Cit., hlm. 6

${ }^{43}$ Ibid

${ }^{44}$ Felix O. Soebagjo dan Erman Rajagukguk, Seri Dasar-Dasar Hukum Ekonomi 2, Arbitrase di Indonesia, Jakarta: Ghalia: Indonesia, 1995, hlm. 2

${ }^{45}$ Pasal 154 Undang-Undang No. 4 Tahun 2009 tentang Pertambangan Mineral dan Batubara.

46 Pasal 155 Undang-Undang No. 4 Tahun 2009 tentang Pertambangan Mineral dan Batubara. 
Indonesia ke adapan ICSID berdasarkan Bilateral Investment Treaty antara Pemerintah RI dengan United Kingdom sebagai kedudukan hukum Churchill Mining plc.

Pasal 7 ayat (1) Bilateral Investment Treaty UK - Indonesia mengatur:

The Contracting Party in the territory of which a national or company of the other Contracting Party makes or intends to make an investment shall assent to any request on the part of such national or company to submit, for conciliation or arbitration, to the Centre established by the Convention on the Settlement of Investment Disputes between States and Nationals of Other States opened for signature at Washington on 18 March 1965 any dispute that may arise in connection with the investment.

Selanjutnya Pasal 2 ayat (1) BIT menyebutkan persyaratan tambahan untuk yurisdiksi yaitu investasi yang dimaksud harus :

have been granted admission in accordance with the Foreign Capital Investment Law No. 1 of 1967 or any law amending or replacing it". It does so in the following terms: This Agreement shall only apply to investments of nationals or companies of the United Kingdom in the territory of the Republic of Indonesia which have been granted admission in accordance with the Foreign Capital Investment Law No. 1 of 1967 or any law amending or replacing it.

Berdasarkan BIT di atas, Churchill menggugat Indonesia ke hadapan arbitrase ICSID. Meskipun ICSID merupakan lembaga penyelesaian sengketa arbitrase yang fleksibel, tetapi hal pertama yang dilakukan adalah menentukan apakah sengketa tersebut termasuk ke dalam kewenangan (yurisdiksi) badan arbitrase ICSID atau tidak. Setelah dinyatakan termasuk ke dalam yurisdiksi ICSID, sengketa tersebut didaftarkan oleh Sekretaris Jendral dan membentuk panel arbitrase yang terdiri dari seorang maupun beberapa orang arbitrator dengan jumlah ganjil sesuai dengan kesepakatan para pihak (biasanya 3 orang). ${ }^{47}$ Yurisdiksi ICSID di sini menunjuk kepada batas-batas berlakunya Konvensi Washington, konvensi yang mendirikan arbitrase ICSID agar badan ini dapat berfungsi.

Yurisdiksi ICSID secara eksplisit diatur dalam ICISD Convention Pasal 25 ayat (1):

The jurisdiction of the Centre shall extend to any legal dispute arising directly out of an investment, between a Contracting State (or any constituent subdivision or agency of a Contracting State designated to the Centre by that State) and a national of another Contracting State, which the parties to the dispute consent in writing to submit to the Centre. When the parties have given their consent, no party may withdraw its consent unilaterally

${ }^{47}$ Faisal Salam, Penyelesaian Sengketa Bisnis Secara Nasional dan Internasional, Mandar Maju, Bandung, 2007, hlm. 451-452. 
Namun perlu dicatat bahwa, sekalipun Pemerintah Republik Indonesia telah meratifikasi konvensi ICSID, tidak berarti secara otomatis setiap sengketa antara investor asing dengan Pemerintah RI harus diselesaikan oleh Dewan Arbitrase ICSID. ${ }^{48}$ Menurut ketentuan dalam Pasal 25 ayat (3) konvensi ICSID disebutkan bahwa dalam suatu persoalan diajukan kepada arbitrase masih dperlukan adanya persetujuan dari pemerina negara yang digugat, yakni pemerintah negara penerima modal. Dengan adanya persetujuan tersebut, ICSID telah membuat suatu modul tentang "arbitration clause" yang dilakukan para pihak, dalam hal ini investor asing dan pihak Indonesia oleh Badan Koordinasi Penananaman Modal (BKPM). ${ }^{49}$ Walaupun negara tuan rumah penerima modal (host country) dan investor asing telah sepakat untuk menyelesaikan sengketanya melalui badan arbitrase internasional, masih terdapat beberapa hal yang menghalang mereka untuk menggunakan badan arbitrase internasional tersebut, misalnya dalam hal proses penyelesaian sengketa merupakan kewenangan pengadilan dari negara yang bersangkutan. ${ }^{50}$ Hal ini yang dikutip oleh para pakar hukum arbitrase yang disebut dengan exhaustion of local remedies. ${ }^{51}$

Berdasarkan Pasal 2 UU No. 5 Tahun 1968 tentang Penyelesaian Perselisihan Antara Negara dan Warganegara Asing Mengenai Penanaman Modal:

Pemerintah mempunyai wewenang untuk memberikan persetujuan bahwa sesuatu perselisihan tentang penanaman modal antara Republik Indonesia dan Warganegara Asing diputuskan menurut Konvensi termaksud dan untuk mewakili Republik Indonesia dalam perselisihan tersebut dengan hak substitusi.

Dalam penjelasan di kemukakan bahwa:

Menurut Pasal 25 ayat (1) dan 36 ayat (2) Konvensi setiap perselisihan harus terlebih dahulu mendapat persetujuan dari kedua belah pihak yang berselisih, sebelum dapat diajukan di depan Mahkamah Arbitrase (Arbitral Tribunal). Dengan pasal ini dipastikan bahwa Pemerintah mempunyai wewenang untuk memberikan persetujuan yang dimaksud itu serta untuk mewakili Republik Indonesia dalam perselisihan tersebut dengan hak substitusi di mana perlu.

Berdasarkan peraturan di atas, yurisdiksi dewan Arbitrase ICSID ditentukan oleh tiga unsur utama yaitu ${ }^{52}$ : a. sengketa harus merupakan sengketa yang muncul secara langsung

\footnotetext{
${ }^{48}$ Sentosa Sembiring, Op. Cit., hlm. 243.

${ }^{49}$ Bambang Sutiyoso, Penyelesaian Sengketa Bisnis: Solusi dan Antisipasi bagi Peminat Bisnis dalam Mengadapi Sengketa Kini dan Mendatang, Cetakan 1, Yogyakarta: Citra Media, 2006, hlm. 206

${ }^{50}$ Faisal Salam, Op. Cit., hlm. 448

51 Aminudin Ilmar, Hukum Penanaman Modal di Indonesia, Jakarta: Kencana, 2004, hlm. 157 dan Bambang Sutiyoso, Op, Cit., hlm. 206

52 Lihat D. Sidik Suraputra, dalam Melda Kamil Ariadno (ed.), Hukum Internasional dan Berbagai Permasalahannya (Suatu Kumpulan Karangan), Jakarta: Lembaga Pengkajian Hukum Internasional Fakultas Hukum UI, 2004, Hlm. 4, Lihat juga R. Subekti, Arbitrase Perdagangan Internasional, Bandung: Binacipta, 1979, hlm. 34. Sedangkan Faisal Salam merujuk pada Pasal 25 Konvensi, 3 syarat pokok yang arus dipenuhi untuk dapat
} 
(arising directly) dari penanaman modal; b. pihak yang bersengketa haruslah negara yang telah menjadi anggota ICSID dan warga negara; c. harus ada pernyataan tertulis, kesepakatan dari kedua belah pihak yang bersengketa, mengenai penyerahan penyelesaian sengketa kepada ICSID.

Permasalahan muncul ketika Indonesia dalam jawabannya atas gugatan Churchill mengelak bahwa telah memberikan persetujuan tertulis untuk membawa kasus ini ke ICSID. Penolakan Indoensia tersebut sangat krusial untuk menjadi pertimbangan Dewan Arbitrase ICSID dalam menentukan yurisdiksinya memutus kasus ini. Pada faktanya, pemerintah Indonesia tidak mengakui kata-kata "shall assent" yang secara harfiah diartikan sebagai kewajiban untuk menyetujui penyelesaian sengketa melalui Arbitrase ICSID, sedangkan Churchill kukuh memegang istilah tersebut sebagai bentuk persetujuan Indonesia untuk menyerahkan penyelesaian sengketa yang timbul dalam investasi ke hadapan ICSID.

Dalam kaidah hukum kebiasaan internasional dan juga diadopsi oleh Indonesia, untuk membawa suatu penyelesaian sengketa ke hadapan arbitrase maka para pihak wajib membuat perjanjian arbitrase. ${ }^{53}$ Perjanjian arbitrase adalah suatu kesepaktan berupa klausula arbitrase yang tercantum dalam suatu perjanjian tertulis yang dibuat para pihak sebelum timbul sengketa, atau suatu perjanjian arbitrase tersendiri yang dibuat para pihak setelah timbul sengketa. ${ }^{54}$ Dengan demikian, bentuk klausula arbitrase dapat dibedakan atas dua bentuk yaitu klausula arbitrase yang berbentuk "pactum de compromittendo" yaitu klausula arbitrase yang dibuat oleh para pihak sebekum terjadi sengketa yang dimuat dalam perjanjian pokok atau perjanjian tersendiri dan "acta compromise" yaitu klausula arbitrase yang dibuat setelah terjadinya sengketa sehubungan dengan pelaksanaan perjanjian pokok yang wajib dibuat secara tertulis. ${ }^{55}$

Dalam penjelasan UU No. 5 Tahun 1968 dikemukakan bahwa walaupun konvensi tersebut tidak berlaku untuk suatu negara, namun tidak ada suatu kewajiban untuk menyelesaiakn setiap perselisihan menurut konvensi. Dalam prakteknya hal itu dilakukan dengan persetujuan secara tertulis dan persetujuan itu bersifat mengikat dan tidak dapat ditarik kembali. Persetujuan tertulis tersebut dapat diwujudkan dalam suatu perundang-

mengajukan sengketanya pada badan arbitrase ICSID yaitu: 1) harus adanya kata sepakat dari para pihak untuk dapat mengajukan sengketanya pada badan arbtrase ICSID; 2) yurisdiksi ratione materiae, artinya sengketa yang dapat diselesaikan oleh ICSID hanya terbatas pada sengketa-sengketa hukum sebagai akibat dari adanya penanaman modal asing saja; dan 3) yurisdiksi ratione personae, artinya badan arbitrase ICSID hanya berwenang mengadili sengketa antara Negara dengan warga Negara asing lain yang negaranya adalah peserta Konvensi, Faisal Salam, Op. Cit., hlm. 452

${ }^{53}$ Pasal 1 Angka 1 Undang-Undang No. 30 Tahun 1999 tentang Arbitrase dan Alternatif Penyelesaian Sengketa. Sengketa.

${ }^{54}$ Pasal 1 Angka 3 Undang-Undang No. 30 Tahun 1999 tentang Arbitrase dan Alternatif Penyelesaian

${ }^{55}$ Bambang Sutiyoso, Op. Cit., hlm. 110-113 
undangan dari negara peserta dengan warga negara dari peserta lain. ${ }^{56}$ Berdasarkan argumentasi ini, maka dapat disimpulkan bahwa sistem two stages yang diajukan Indonesia sebenarnya tidak perlu, sebab dengan telah disahkannya BIT dengan klausula arbitrase di dalamnya telah nyata menunjukkan konsen bagi bangsa Indonesia untuk menyelesaikan sengketa tersebut di adapan ICSID. Selain itu, BIT Indonesia - UK tersebut berupa hardcopy atau tertulis sehingga keabsahannya tidak perlu dipertanyakan lagi.

\section{Penutup}

Tujuan utama suatu BITs adalah untuk meningkatkan promosi dan proteksi "reciprocal encouragement" investasi di wilayah asal masing-masing perusahaan. Tujuan utama BITs adalah untuk melindungi investasi di luar negeri, meningkatkan kebijakan yang berorientasi pasar dan menciptakan praktek investasi yang transparan dan non diskriminasi antara negara dan investor, dan untuk mendukung perkembangan standar hukum internasional yang sejalan dengan tujuan-tujuan tersebut.

Seiring berkembangnya waktu pelaksaan perjanjian BIT yang dilaksanakan oleh Indonesia pada saat ini dirasa telah banyak merugikan Indonesia sebagai host country dan menganggap perjanjian tersebut sudah tidak relevan lagi dan perlu untuk diadakannya pembaharuan perjanjian BIT. Dengan langkah berani Indonesia untuk mengakhiri Bilateral Investment Treaty dan bermaksud untuk merenegosiasikannya dengan negara lain, maka inilah waktu yang sangat tepat bagi pembuat kebijakan Indonesia untuk bersama-sama dengan satu tujuan yaitu untuk memahami substantive issue dari perjanjian investasi dan menghasilkan model atau pedoman BIT model Indonesia berdasarkan maksud dan tujuan investasi yang diinginkan Indonesia. Hal ini sangat penting agar BIT Indonesia selalu konsisten dalam memberikan perlindungan bagi investor asing dan sekaligus menjadi kendaraan yang mengantarkan Indonesia memenuhi kepentingan ekonomi nasionalnya. Mengingat bahwa dampak BIT pada akhirnya sangat signifikan terutama dalam hal penyelesaian sengketa antara Indonesia dengan investor asing dan seringkali berujung kepada ganti rugi yang sangat besar yang harus dibayarkan pemerintah, maka membuat BIT Model Indonesia dan policy guideline yang jelas merupakan upaya yang harus diwujudkan pemerintah Indonesia.

ICSID memiliki yurisdiksi untuk menangani sengketa antara pemerintah RI dengan Churchill Mining plc sebab Churchill Mining merupakan 1) investor asing yang menanamkan modalnya di Indonesia melalui PT. ICD dan melakukan perjanjian dengan

56 Aminudin Ilmar, Op. Cit., hlm. 160 
investor lokal Indonesia yang turut menanggung kerugian atas dicabutnya IUP anak perusahaan PT. Ridlatama; 2) Indonesia merupakan negara anggota ICSID karena telah meratifikasi Konvensi ICSID bersama-sama dengan Inggris sebagai negara asal Churchill Mining plc; dan 3) Bilateral Investment Treaty dapat menjadi rujukan adanya klausul arbitrase berupa pactum de compromittendo bahwa Indonesia secara tertulis telah sepakat untuk membawa penyelesaian sengketa di negaranya di ICSID.

Saat ini proses penyelesaian sengketa antara Churchill Mining plc dengan pemerintah Indonesia masih bergulir di Dewan Arbitrase ICSID. Putusan bahwa yurisdiksi memiliki wewenang menangani sengketa antara pemerintah Indonesia dengan Churchill Mining plc seharusnya tidak membuat pemerintah Indonesia kecewa dan merasa gagal untuk mempertahankan argumentasinya di hadapan Arbitrase ICSID. Sebagai strategi ke depan, pemerintah Indonesia perlu membuktikan bahwa izin yang dimiliki oleh anak-anak perusahaan PT. Ridlatama adalah palsu berdasarkan apa yang menjadi dasar pencabutan Izin Usaha Pertambangan anak-anak perusahaan tersebut. Dengan pembuktian tersebut, dapat menjadi dasar bahwa perjanjian antara PT. ICD sebagai perusahaan yang sebagian besar modalnya dimiliki Churchill Mining plc sehingga ia memiliki hak untuk menuntut pemerintah Indonesia atas kerugiannya dengan anak-anak perusahaan PT. Ridlatama menjadi tidak sah berdasarkan syarat sah perjanjian yang tercantum dalam Pasal 1320 KUHPerdata yaitu melanggar klausa yang hal. Dengan demikian, perjanjian tersebut menjadi null and void atau batal demi hukum sehingga Churchill Mining plc tidak bias semata-mata menuntut Pemerintah Indonesia atas kerugian yang dideritanya.

\section{Daftar Pustaka}

Ali, Zainuddin, Metode Penelitian Hukum, Sinar Grafika Ofsset, Jakarta, 2009.

Boone, Joshua, How Developing Countries Can Adapt Current Bilateral Investment Treaties To Provide Benefits To Their Domestic Economies, GLOBAL BUSINESS LAW REVIEW, Vol. 1:187 (2011).

Carim, Xavier, Lessons from South Africa's BITs Review, Columbia FDI Perspectives, Perspectives on topical foreign direct investment issues by the Vale Columbia Center on Sustainable International Investment No. 109, November 25, 2013.

Chalamish, Efraim, The Future of Bilateral Investment Treaties: A De Facto Multilateral Agreement?, 34 Brook. J. Int'1 L. 303, 307-08 (2009).

Dolzer, Rudolf, The Impact of International Investment Treaties on Domestic Administrative Law, 37 N.Y.U. J. Int'l L. \& Pol. 953, passim (2005). 
Ginsburg, Tom, International Substitutes for Domestic Institutions: Bilateral Investment Treaties and Governance, 25 INT'L REV. L. \& ECON. 107, 108 (2005).

Ibrahim, Johny, Teori Metodolgi Penelitian Hukum Normatif. Banyu Media, Malang, 2008

Ilmar, Aminudin, Hukum Penanaman Modal di Indonesia, Kencana, Jakarta, 2004.

J. Bubb, Ryan dan Susan Rose-Ackerman, BITs and Bargains: Strategic Aspects of Bilateral and Multilateral Regulation Of Foreign Investment, 27 Int'l Rev. L. \& Econ. 291 (2007)

J. Vandevelde, Kenneth, The Economics of Bilateral Investment Treaties, 41 HARV. INT'L L.J. 469, 471 (2000)

Jamieson, Sara, A Model Future: The Future of Foreign Direct Investment and Bilateral Investment Treaties, 53 S. Tex. L. Rev. 605 (2012

Mahmud Marzuki, Peter, Penelitian Hukum, Kencana Persada Group, Jakarta, 2010.

Medioambientales TECMED S.A. v. United Mex. States, ICSID Case No. ARB (AF)/00/2, Award, P 160 (May 29, 2003), 10 ICSID Rep. 130 (2006)

Mutiara Virjinia, Citra, Pelaksanaan Bilateral Investment Treaties (BIT) Dalam Penanaman Modal Asing d iIndonesia Berdasarkan Undang-Undang No. 25 Tahun 2007 Tentang Penanaman Modal, Jurnal Universitas Padjajaran.

Newcombe, Andrew \& Lluis Paradell, Law and Practice of Investment Treaties: Standards of Treatment $\S 2.30$ (Kluwer Law International 2009.

Novia Heriani, Fitri dan Robert Sidauruk, Govt Requests ICSID to Discontinue Churchill Mining, Case, http://en.hukumonline.com/pages/ lt53c3903dc8295/govt-requestsicsid-to discontinue-churchill-mining-case.

O. Soebagjo, Felix dan Erman Rajagukguk, Seri Dasar-Dasar Hukum Ekonomi 2, Arbitrase di Indonesia, Jakarta: Ghalia: Indonesia, 1995.

R. Reading, Michael, The Bilateral Investment Treaty in Asean: A Comparative Analysis, 42 Duke L.J. 679 (1992).

Salam, Faisal, Penyelesaian Sengketa Bisnis Secara Nasional dan Internasional, Bandung: Mandar Maju, 2007

Sembiring, Sentosa, Hukum Investasi, Nuansa Aulia, Bandung, 2010.

Sumardjono, Maria S.W. Pedoman Pembuatan Usulan Penelitian Sebuah Panduan Dasar, PT. Gramedia Pustaka Utama, Jakarta, 1997.

Sutiyoso, Bambang, Penyelesaian Sengketa Bisnis: Solusi dan Antisipasi bagi Peminat Bisnis dalam Mengadapi Sengketa Kini dan Mendatang, Cetakan 1, Yogyakarta: Citra Media, 2006.

Wong, Jarrod, Umbrella Clauses in Bilateral Investment Treaties: Of Breaches of Contract, Treaty Violations, and the Divide Between Developing and Developed Countries in Foreign Investment Disputes, 14 Geo. Mason L. Rev. 135, 141 (2006).

W. Salacuse, Jeswald \& Nicholas P. Sullivan, Do BITs Really Work?: An Evaluation of Bilateral Investment Treaties and Their Grand Bargain, 46 Harv. Int'l L.J. 67, 67 (2005).

W. Situmorang, Johnny, Menguak Iklim Indonesia Pascakrisis, ESENSI, Jakarta: 2011 
Yacob Rihwanto. Bilateral Investment Treaties... 125

http://www.thejakartapost.com/news/2014/07/07/revamping.bilateraltreaties.html\#sthash. CINhOB8d.dpuf edis. 